\title{
Public Tenders for Music Teachers in the South of Brazil
}

\author{
Cristina Rolim Wolffenbüttel ${ }^{1}$ \\ ${ }^{1}$ Music Department, State University of Rio Grande do Sul, Montenegro, Brazil \\ Correspondence: Cristina Rolim Wolffenbüttel, Capitão Porfírio Street, 2141, Montenegro, Rio Grande do Sul, \\ Brazil. Tel: 555-199-809-2393.
}

Received: August 7, 2019

Accepted: August 29, 2019

Online Published: September 6, 2019

doi:10.20849/aes.v4i2.628

URL: https://doi.org/10.20849/aes.v4i2.628

\begin{abstract}
This article presents the research that investigated the performance of open procedure for music teachers in municipal schools in Rio Grande do Sul, (a) state in the south of Brazil. The methodology included Internet research and, for data analysis, Content Analysis. The theoretical reference was based on concepts of Musical Education marked by the Policy Cycle Approach. Considering the 2008 mid-2017 time cut-off, sixty (public) notices were identified for the hiring of music teachers. Out of the 497 municipalities that make up the state, 133 conducted Employment tests. Still, it is understood that there are great challenges for the presence of music in state schools.
\end{abstract}

Keywords: musical education, public policies, open procedure

\section{Introduction}

Since the arrival of the Royal Family in Brazil, public policies in education have been implemented to guarantee quality and access to education in the country, meeting the interests of the national order. In the case of music teaching, the legislative trajectory began from Decree No 1.331-A, of February 17, 1854, which approved the regulation for the reform of primary and secondary schools of the Court Municipality observing the mention of music learning, among other school competences in Article 47 primary education, and in Article 80 secondary education, in addition to the curriculum structure for the Education of the time (BRASIL, 1854).

Music education therefore has a long historical path in Brazil, being present in the country practically since its discovery. Lemos Junior (2012) points out that specific training for music teachers was requested only in 1890. Despite the legal demands of the time, there was no strengthening of music in schools, and only since 1920 some contributions favored the expansion of its teaching along with the educational articulations promoted by the New School, highlighting Orpheonic Singing, by Villa-Lobos, in formal environments of education (LEMOS JÚNIOR, 2012).

With the proposal of the Orpheonic Singing and the reforms in Brazilian education, in 1931 and 1942 the teaching of music became mandatory in primary and secondary schools. Years later, in 1964, some adaptations were made to Brazilian education resulting in the exchange of the nomenclature Orpheonic Singing for Musical Education (LEMOS JÚNIOR, 2012).

In the analysis of the laws relating to national education, relations about the presence of music in schools are understood. The following legislation is highlighted: Law No 4.024/61, Law No 5.540/68, Law No 5.692/71, Law No 7.044/82, Law No 9.131/95, Law No 9.192/95, and Law No 9.394/96 (BRASIL 1961, 1968, 1971, 1982, 1995a, 1995b, 1996).

Amid the legislative changes, the specificity of music teaching was removed from school curricula. The National Education Guidelines and Bases Law No 5.692, from 1971, instituted the teaching of artistic education in elementary and high school throughout the country (BRASIL, 1971), at that time, named 1st and 2nd degrees, respectively. From this law, the specific contents of the artistic languages, especially music, were emptied, in favor of an education called multipurpose. According to Hentschke and Oliveira (2000), in the 1970s there was a predominance of the educational trend whose emphasis was more on the expressive aspect of the individuals. Attention in the teaching and learning process meant greater emphasis on the process, rather than the product.

With the approval of the Law No 9.394/96 (BRASIL, 1996), other contributions were allocated to education. In this regard, this law established the principles and purposes of education, ensured access to its rights and duties, its 
organization, its levels of education for all Brazilian Basic Education, which comprises Preschool, Primary and Secondary Education, in addition to teaching modalities such as Youth and Adult Education, Professional and Special Education, as well as Higher Education (BRASIL, 1996). However, with regard to music teaching, there was no specificity; however, there was mention of art teaching, without specifications about which language would be implemented.

Faced with the legislation that resulted insertions and discontinuities in music teaching, researchers conducted investigations, seeking to understand the context of its operationalization. Penna (2004a, 2004b), when investigating the educational policy for the teaching of the arts in elementary and high school, from the legislation and the normative terms of music teaching, discussed the educational policy for the teaching of the arts with emphasis on the analysis of Law No 5.692/71 (BRASIL, 1971) and later in the Opinion of the Federal Council of Education No 1.284, from 1973 (BRASIL, 1973), pointing out continuities and changes that occurred between the 1970s and 1990 (PENNA, 2004a).

According to the author, in the text of Law No 5.692/71 there was no clear definition of which artistic languages should be included in schools (PENNA, 2004a). Subsequently, Federal Council of Education Opinion No 540/77 pointed out the inadequacy of the focus on the area in previous years, stating that at that time music teaching focused only on musical theory and the practice of choral singing, the teaching of artistic education would no longer involve such approaches. Under this aspect therefore, and considering an integration between the artistic areas, music was in the field of Artistic Education (BRASIL, 1977).

As the years passed, efforts were intensified to make more specific the normative precepts for music teaching, evidenced in the opinions of the Federal Council of Education from 1973 and 1977 (PENNA, 2004a: 21). Despite the fact that Law No 9.394/96 established the teaching of the arts as a mandatory curriculum component in the various levels of Basic Education, there were still indefiniteness and ambiguities, allowing multiple interpretations regarding this teaching (practice) (PENNA, 2004a).

Faced with this scenario, musical educators and researchers mobilized to separate the fields of art in school education, making them specific. Despite the legal changes in reality teaching was still called artistic education. In this regard since then research has sought to understand public policies for teaching music in Basic Education (REQUIÃO, 2013; QUEIROZ; PENNA, 2012; DEL BEN, 2005; DINIZ, 2005; SANTOS, 2005; PENNA, 2002, 2004a, 2004b; SOUZA et al, 2002).

In addition to the legislation that guarantees the teaching of music in schools, researchers have also found over the years the scarce presence of music teachers in Basic Education (PENNA, 2002, 2004a, 2004b; SANTOS, 2005; DEL BEN, 2005). The relevance of the discussions on this subject for education as a whole is therefore understood.

With the Law No 11.769, August 18, 2008 (BRASIL, 2008), which provides on the compulsory teaching of music in Basic Education, the legislation for the insertion of music in schools received an increment. This law should have entered into force in three years, that is, in 2011. However, over the years, it has been observed that the established normative terms have not been complied with.

To support the importance of music teaching in Brazilian schools, in 2013 the National Council of Education, in partnership with the Brazilian Association of Musical Education, held several public audiences, resulting in the elaboration of Opinion No 12/2013, the National Chamber of Education and the Chamber of Basic Education (BRASIL, 2013). It should be noted that this opinion was only approved on May 102016 (BRASIL, 2016), as will be mentioned below in this article.

The actions of the National Council of Education took effect in some Brazilian municipalities. In the state of Rio Grande do Sul (RS), Del-Ben and collaborators (2016) observed the movement of some municipalities that launched tender notices for music teachers between the years (of) 2008 and 2012. However, these actions have not been sufficient for the insertion of music in schools, despite all the effort it is still perceived difficulties for state and municipal education systems to comply with the legislation (DEL-BEN et al, 2016).

Figueiredo and Meurer (2016) present the impacts of this law in the states of the southeast of the country, highlighting that among other aspects observed "music seems to be occupying a curricular space if it is considered the presence of music graduates in basic education, which represents an achievement for the area of musical education" (FIGUEIREDO; MEURER, 2016: 536).

Law No 13.278 May 2, 2016, amended paragraph 6 of Article No 26 of Law No 9.394/96, which focuses on the teaching of art, including visual arts, dance, music, and theatre as the languages which will become curricular components (BRASIL, 2016a). This law also established the period of five years for the implementation of these 
changes in Brazilian schools. Days after, on May 10, 2016, Resolution No 2 was published, which "Defines National Guidelines for the operationalization of Music Education in Basic Education" (BRASIL, 2016b), containing guidelines, as defined by Law No 11.769/2008, in its various stages and modalities, aimed at the secretariats of education, training institutions of music professionals and teachers, the Ministry of Education and the Councils of Education.

Therefore, the insertion of music teaching in Brazilian schools, through the provisions laid down in the legislative texts, which focus on the normatizations of national education, are punctually significant and mark this article, which presents the results of research on the performance of public tenders for music teachers of Basic Education in the municipalities of Rio Grande do Sul, in southern Brazil. It was guided by the following questions: How many and which education departments promoted public tenders for the entrance of music teachers in entities of their school network? If these public tenders took place, when did they take place? What is the relationship between the date of these tenders and the date of Law No 11.769/2008?

\section{Method}

The methodology used in this research included the use of Internet research for the data collection, considering "that the time between the moment the information is provided and the dissemination of the results considerably decreases" (FREITAS; MUNIZ; MASCAROLA, 2004: 2). This type of research provided access to various data, allowing greater coverage and lower cost, justifying its use.

The procedures used were surfing on the Internet, browsing search for links and search for words related to public tenders for music teachers, proposed by Koch (1996). In addition to the search for public tender websites, scans were conducted on the website of the secretariats of education of the municipalities of Rio Grande do Sul, checking records and/ or public tender announcements for music teachers.

In the data analysis, the five stages proposed in the Content Analysis by Moraes (1999) were implemented, namely, preparation of information, unitarization or transformation of content into units, categorization or classification of units into categories, description and interpretation. The first stage, preparation, consisted of reading the data collected in full, deciding on which of them were effectively in accordance with the objectives of the research. After that, a unitarization was performed, with careful reading of all the material, defining the unit of analysis. Subsequently, all materials were reread, identifying the units of analysis and coding. The categorization consisted in grouping the data considering the common part between them, being classified by similarities or analogies, originating thematic categories. Table 1 presents the resulting categories, as the specification of the professional acting area indicated in the hiring notices for teachers, namely, Arts, Art/Music, Artistic Education, Teaching of Arts, Music Instructor, Music and Director Company. It should be clarified that the names presented in the categorizations are those listed on the websites and indicated by the companies that carried out the entire selection process.

Table 1. Data analysis categories

\begin{tabular}{ll}
\hline \multicolumn{2}{c}{ Data Analysis Categories } \\
\hline Category I & Arts \\
\hline Category II & Art/ Music \\
\hline Category III & Artistic Education \\
\hline Category IV & Teaching of Arts \\
\hline Category V & Music Instructor \\
\hline Category VI & Music \\
\hline Category VII & Director Company \\
\hline
\end{tabular}

Source: the author

In the fourth stage, data description, synthesis texts of information organized in each of the seven categories were produced, focusing on the realization of public tenders for music teachers in the state of Rio Grande do Sul, in southern Brazil. Which and how many secretariats of education promoted public tenders for music teachers was described, whether or not these tenders have been promoted and when they will take place, as well as the relationship between the date of promotion of these tenders and the date of the Law No 11.769/2008. 
The interpretation, the final stage, consisted of articulating the analysis of the data collected, relating them to the specialized literature and other research experiences, with musical education and the Policy Cycle Approach being the theoretical analytical reference material used.

\section{Theoretical Analytical Benchmark}

The reference used for the analysis of the research data was based on the epistemological concepts of musical education, with Kraemer's work (2000) as a marker, as well as the studies by Bowe et al (1992) and Ball (1994), featured in the Policy Cycle Approach.

\subsection{The Musical Education}

Kraemer (2000) discusses musical education - calling it the pedagogy of music - as an imbrication between disciplines, discussing dimensions and functions of pedagogical-musical knowledge and highlighting the particularities of the area in relation to the other disciplines. The author describes the places in which the pedagogy of music originates, as well as those it occupies. In his analysis, the author explains that the pedagogy of music is concerned with the relationships between persons and musics, dividing its study object with the humanities. He exemplifies these disciplines, focusing on the philosophical, historical, psychological, sociological, musicological, pedagogical and other disciplines that can have an important pedagogical-musical meaning.

The sociological aspects pointed out by Kraemer (2000) start from the sociology of music, examining the effects of music, social conditions, and social relations related to music. Man is observed in the institutionalized and organized areas of education, including "socialization processes, institutions and forms of organization, profession, groups of the same age, legal and economic means and conditions" (KRAEMER, 2000: 57).

The pedagogical aspects start from pedagogy, which is concerned with "with theories of education and training, premises, conditions, processes and consequences of educational and didactic action, with social and institutional issues, with problems of teaching, learning and didactics" (KRAEMER, 2000: 59). There are other disciplines that can present a special pedagogical-musical meaning, such as political sciences, pedagogy of art, legal issues, pedagogical-religious, economic, to cite some of the existing possibilities (KRAEMER, 2000).

Kraemer (2000) discusses the interweaving of music pedagogy with other disciplines. It is evident that a perspective of intertwining of the area considers it as a result of the mutual bond between the disciplines, creating a kind of web. This interweaving concept proposes a broad area with more comprehensive and flexible boundaries.

According to Kraemer (2000: 61), at the center of the musical reflections are the problems of the appropriation and transmission of the music". The particularity of pedagogical-musical knowledge is at the "crossroads of pedagogical ideas marked by the humanities, guided by musical culture and aesthetic-musical ideas" (KRAEMER, 2000: 66). For the author, besides the knowledge about facts and pedagogical-musical contexts, it is also necessary to make available the principles of explanation of the musician-educational practice, for the decisions, orientations, clarifications, influence and optimization of these practices (KRAEMER, 2000).

Finally, Kraemer (2000) proposes a structural model of the pedagogy of music that includes the analysis and the fields of application of the area, the aspects that compose it -musicological, pedagogical, among others - besides the functions of music pedagogy - understand and interpret, describe and clarify, raise awareness and transform the musician-educational practice.

The choice of Kraemer's concepts (2000) for the analysis of the data of this investigation allowed the discussion about the relations between professionals to whom public tenders were destined, understanding, interpreting, describing, clarifying, raising awareness and glimpsing possibilities of transformation of the musician-educational practice originated from the realization of the public tenders, in the places where they occurred.

\subsection{The Policy Cycle Approach}

Bowe et al (1992) and Ball (1994) proposed the characterization of the political process through the Policy Cycle Approach. For the authors, by introducing the idea of a continuous cycle of policy, it is objectivated attract attention to the political recontextualization that transits through schools. However, the panorama of school research requires considering not only a national curriculum, but also other elements that constitute the educational policy (BOWE et al, 1992). There is a cycle composed of contexts that influence and are influenced, these being the contexts of influence, political text, practice, effects and political strategy.

The context in which policy is initiated, in which political speeches are constructed and interested parts struggle to influence decisions is that of influence. The second context of the political text consists of the representative policy texts. Such representations may be presented as legal texts, official guiding documents, formal or informal 
comments, speeches, public presentations by politicians and key officials, official videos, among other representations (BOWE et al, 1992). The authors explain that policies are textual interventions, but carry limitations and possibilities. The answer to these texts has real consequences, being experienced in the context of practice. This context is the arena of practice to which policy is directed. It is not simply received and implemented in this scenario, but it is subject to interpretation, and can even be recreated, therefore, according to Bowe et al (1992), the people who implement policies do not confront the political texts so naively.

Later on, Ball (1994) expanded the Policy Cycle Approach, adding two contexts: effects and political strategy. The context of the effects is concerned with the issues of justice, equality and individual freedom. The effects of policies may be presented as general and specific effects. The general effects of a policy are presented when specific aspects of change and sets of responses - which in turn appear in the context of practice - are grouped and analysed. The general effects of policies are sometimes neglected in more detailed studies regarding changes or political texts as determinants of the impact on practice. If analysed in isolation, the specific effects may seem limited. Ball (1994) suggests then that the analysis of a policy involves the examination of these two dimensions, as well as the interfaces of the policy under study with other sectorial policies and with all the policies.

Finally, the context of the political strategy involves the identification of a set of social and political activities necessary to deal with the inequalities originated by the policy under study. This component is essential for critical social research, and this work is produced for strategic use in specific social situations and clashes (BALL, 1994).

The Policy Cycle Approach, one of the theoretical-analytical markers of this research, was crucial for the understanding of how the implementation of some public tenders happened intertwined to the contexts of the approach.

\section{Results}

The research analysis corpus was constituted between August 2016 and July 2017. It was considered a time frame for the selection of notices, regarding the public tenders occurred between 2008, since the Law No $11.769 / 2008$, and the first quarter of the year 2017, according to the schedule previously prepared for the research.

Of the 497 municipalities that constitute the state of Rio Grande do Sul, 133 held public tenders in order to hire music teachers and/or that thus allowed the interpretation that professionals with higher education in Art/Music could participate in the selection process. From the data, it is observed that, regarding the amount of municipalities of the state, 364 did not held public tenders in order to hire music teachers, which means $73.23 \%$. So, only about $26.76 \%$ of the municipalities held tenders for this purpose, which is a much lower number given the need presented in the south of Brazil.

Although the data collected included the year 2008, only starting in 2010 the municipalities of Rio Grande do Sul began to make it explicit in their notices the specific formation in music. This data is worrisome considering the insertion of music in schools. According to Kraemer (2000), the appropriation of pedagogical-musical knowledge by professionals who work with the musical teaching contributes to the established relationship with the socialization of knowledge relevant to the area. The data can be observed in Table 2, which presents the number of tenders offered through notices, in their respective years of realization, which adds to a total of 60 .

Table 1. Publication of notices for the hiring of music teachers

\begin{tabular}{lc}
\hline Year & Number of Public Tenders Held \\
\hline 2008 & 0 \\
\hline 2009 & 0 \\
\hline 2010 & 4 \\
\hline 2011 & 4 \\
\hline 2012 & 10 \\
\hline 2013 & 3 \\
\hline 2014 & 16 \\
\hline 2015 & 13 \\
\hline 2016 & 7 \\
\hline 2017 & 3 \\
\hline Total & 60 \\
\hline
\end{tabular}

Source: the author 
Kraemer (2000: 57) explains that "political beliefs have a significant role in the discussion regarding the definition of objectives, interpretation and conception of education and musical formation". Thus, when considering for analysis the notices intended for hiring professionals with formation in music, it is important to relate their dates of publication in addition to the indicative for the teacher's performance according to the school years that constitute Basic Education, corroborating the social and political importance of access to school musical education.

According to Bowe et al (1992), the context of influence is constituted by the speeches that corroborated political decisions, contributing to the process of elaborating the political text. Such decisions may result in legal texts or official guiding documents. It is understood that the adoption of Law No 11.769/2008 contributed to the understanding of the need to insert music in schools. However, the interpretation of the political text generated different understandings by the municipal administration as to the effective practical adjustments of the municipalities in order to enable access to their teaching to students of their schools.

It was observed, from the data collected, that during the years 2008 and 2009 there was no public tender to hire music teachers, which occurred only in 2010 , with the publication of four notices requesting formation in the area. The year 2011 also maintained this incidence. In 2012 there was an increase in the publication of notices issued with the goal of hiring music teachers, with ten public tenders.

The lowest incidence of notices issued with the goal of hiring music teachers was in 2013, with three notices, 2016 with seven notices, and 2017 with three notices identified.

The period between 2014 and 2015, compared to the other years of this research, stood out in number of notices issued for music teachers, with a total of sixteen notices (2014) and thirteen notices (2015).

Considering the years from 2008 to 2017 , there were sixty notices for music teachers and/ or booking registration, highlighting the municipality of Campo Bom, with the publication of ten notices during this period. This municipality promoted selection processes for music teachers between 2011 and 2013 through a notice published in each of the years. Job vacancies were also offered for music teachers in three notices in 2014, two in 2015, a notice in 2016 and a notice in the first quarter of 2017.

In view of the context of the effects (BALL, 1994), regarding the changes in policy texts as determinants for the impact of legislative practice, policy analysis may involve strategic dimensions and distinct sectoral interfaces. Therefore, the context of the policy strategy involves the identification of a set of social and substantially political activities in the context of practice (BALL, 1994). It was sought, therefore, to understand how the municipalities understand the need of access to music in their schools, which is synthesized in Table 3.

Table 3. Indicative of action in basic education

\begin{tabular}{ll}
\hline Indicative of Action & $\begin{array}{l}\text { Number of open procedures } \\
\text { awarded }\end{array}$ \\
\hline Preschool / Elementary School - Early and Final Years & 1 \\
\hline Elementary school - Early years & 1 \\
\hline Elementary school - Final Years & 19 \\
\hline Elementary school - Early and Final Years & 1 \\
\hline Elementary school & 8 \\
\hline Elementary school - Final Years / High School & 2 \\
\hline Elementary school - Final Years and or High School & 1 \\
\hline High School & 1 \\
\hline Basic Education & 1 \\
\hline No indication & 25 \\
\hline Total & 60 \\
\hline
\end{tabular}

Source: the author

According to Table 3, with greater incidence, the notices analyzed do not identify in which year of Basic 
Education the professional to be hired will exercise teaching in music, they just point out the teaching levels and some specifications, as early years, final years, High School and Basic Education, for example. For the performance in Preschool, only one indicative was identified for teaching in this school phase, while the specification also designates the professional performance of teachers in the early and final years of elementary school.

The hiring of professionals to work in the final years of elementary school occurred with the highest incidence, with 19 being identified among the 60 notices analyzed that directed professional performance of the music teacher to this school phase. In addition, 8 notices were identified that aimed at hiring music teachers for the early and final years of elementary school, and 3 notices for high school. Also only one public notice intended to hire music teachers for Basic Education. This observation corroborates the practical perspective for the interpretation of the political text, according to Bowe et al (1992) and Ball (1994), which relate the analysis of public policy in education.

The interpretation of the political text regarding the compulsory teaching of music in Brazilian schools - based on Law No 11.769/2008 and Resolution No 2/2016 - still seems to present multiple interpretations on the effective importance of access to music, as well as on the relevance of hiring professionals with specific formation in the field of music for the professional performance in this teaching. Data indicate disparities in access to music in schools in in the state of Rio Grande do Sul.

Table 4 presents the promotion of public tenders to hire teachers artistic education, whose specification was changed through Law No 9.394/96. However, even if the name of the curriculum component has been changed by law, including college-level course adjustments to the new specificities of the area, there are public notices issued between the years 2010 and 2017 that interpret the political text taking into account the interest in hiring multipurpose teachers for teaching arts in schools. Such notices include the participation of artistic education teachers, according Law No 5.692/71, which is no longer in force.

Table 4. Promotion of public tenders for music teachers

\begin{tabular}{lc}
\hline Year & Number of Public Tenders Held \\
\hline 2008 & 0 \\
\hline 2009 & 0 \\
\hline 2010 & 3 \\
\hline 2011 & 3 \\
\hline 2012 & 3 \\
\hline 2013 & 1 \\
\hline 2014 & 5 \\
\hline 2015 & 7 \\
\hline 2016 & 3 \\
\hline 2017 & 4 \\
\hline Total & 29 \\
\hline
\end{tabular}

Source: the author

In this aspect, it is highlighted what the Policy Cycle Approach allows us to analyze. Although the legislation has long been calling for compulsory music teaching, as well as a break with the concept of polyvalence in the arts when it comes to teacher formation, such practices still persist. This is an example of reinterpretation, as Bowe et al (1992) and Ball (1994) postulate.

From 2010 to 2012 (there) were three notices found in each year, being aimed at hiring professionals with formation in artistic education. A 2013 public notice indicated this formation at a higher level. In the following two years there was an increase in the number of public notices for the hiring of artistic education teachers, being five notices in 2014, and seven in 2015. Between 2016 and 2017 there were three and four notices identified, respectively. 
The notices for art teachers were also found, in addition to other nomenclatures, as formation under Article 63, Law No 9.934/96 and other current legislation, higher course in artistic education and artistic education (visual arts, dance, music, and theater), which are open to interpretation regarding the participation of music teachers, a fact that relates to the context of the political text (BOWE et al, 1992).

\begin{tabular}{|c|c|c|c|c|c|c|c|c|c|c|c|c|c|c|}
\hline \multirow[t]{3}{*}{ 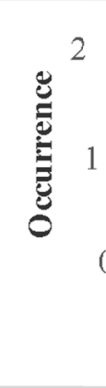 } & & 00 & 00 & $\begin{array}{lll}0 & 0 \\
0\end{array}$ & $\begin{array}{lll}0 & 0 \\
\end{array}$ & $0_{0}^{1}$ & 00 & 0 & & 2 & & $\frac{1}{10}$ & & 0 \\
\hline & \multirow{2}{*}{0} & \multirow[t]{2}{*}{2008} & 2009 & 2010 & 2011 & 2012 & 2013 & & & & & 201 & \multicolumn{2}{|c|}{2017} \\
\hline & & & 2008 & 2009 & 2010 & 2011 & 2012 & 2013 & & 014 & 2015 & & 2016 & 2017 \\
\hline \multicolumn{3}{|c|}{ ه Art/Music } & 0 & 0 & 0 & 0 & 0 & 0 & & 0 & 2 & & 1 & 0 \\
\hline \multicolumn{3}{|c|}{$\square$ Art Music/Others } & 0 & 0 & 0 & 0 & 1 & 0 & & 1 & 0 & & 0 & 0 \\
\hline
\end{tabular}

Source: the author

Figure 1. Implementations of public tenders for arts and arts/others

According to Figure 1, as for the notices for arts teachers - music, there were two notices identified, one (issued in 2012 and another in 2014. With the formation specifications in the area of arts - music/others - qualifications in the area of art in their diversities (visual arts, dance, music, and theater), two public tenders held in 2015 were identified, and a public tender in 2016, totalizing three tenders with this specification.

Figure 2 relates the incidence of public tenders, according to the years of publication of the notices for qualifications in artistic education or arts, teaching arts and art teachers whose formation was required at a higher education level in that area of professional performance.

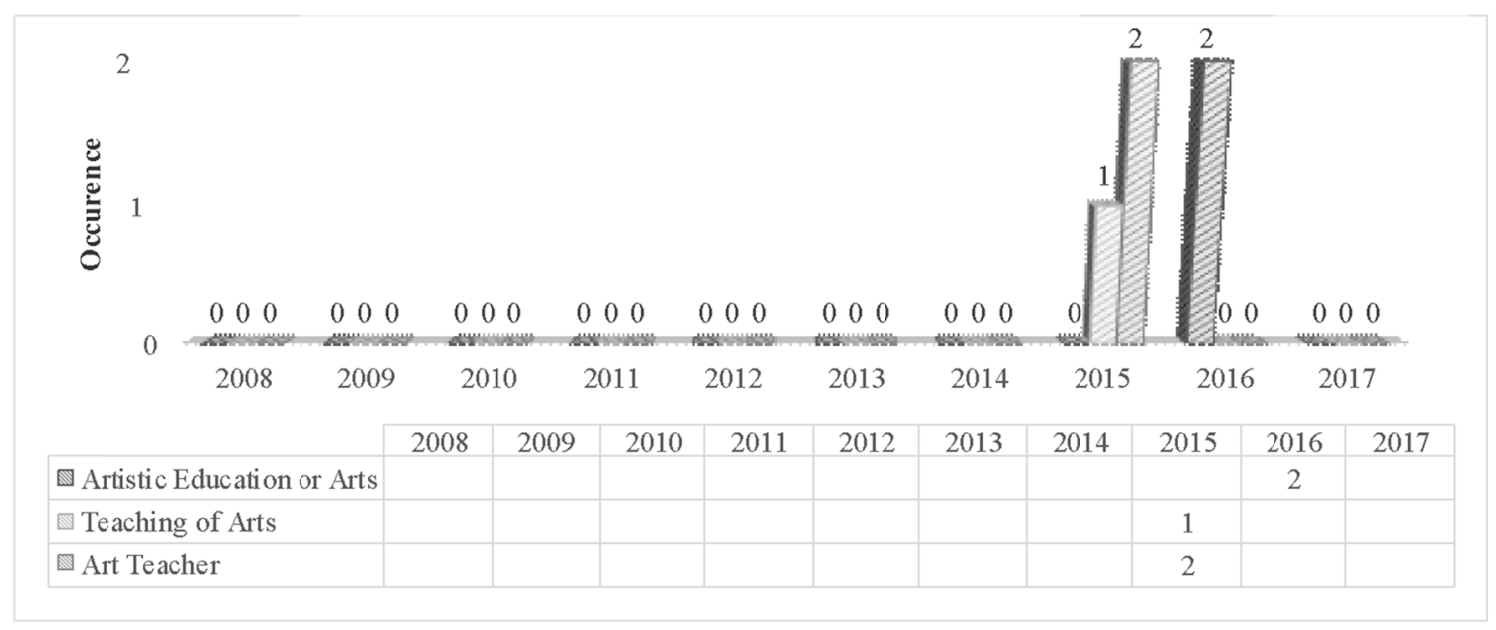

Figure 2. Public tenders for art education or arts, art teaching and art teachers

Source: the author

For formation in artistic education or arts there were two tenders held in 2016. For the teaching of arts, a public tender was held in 2015 , and with the specification for art teacher there were two public tenders held in 2015 , as presented in Figure 3. 


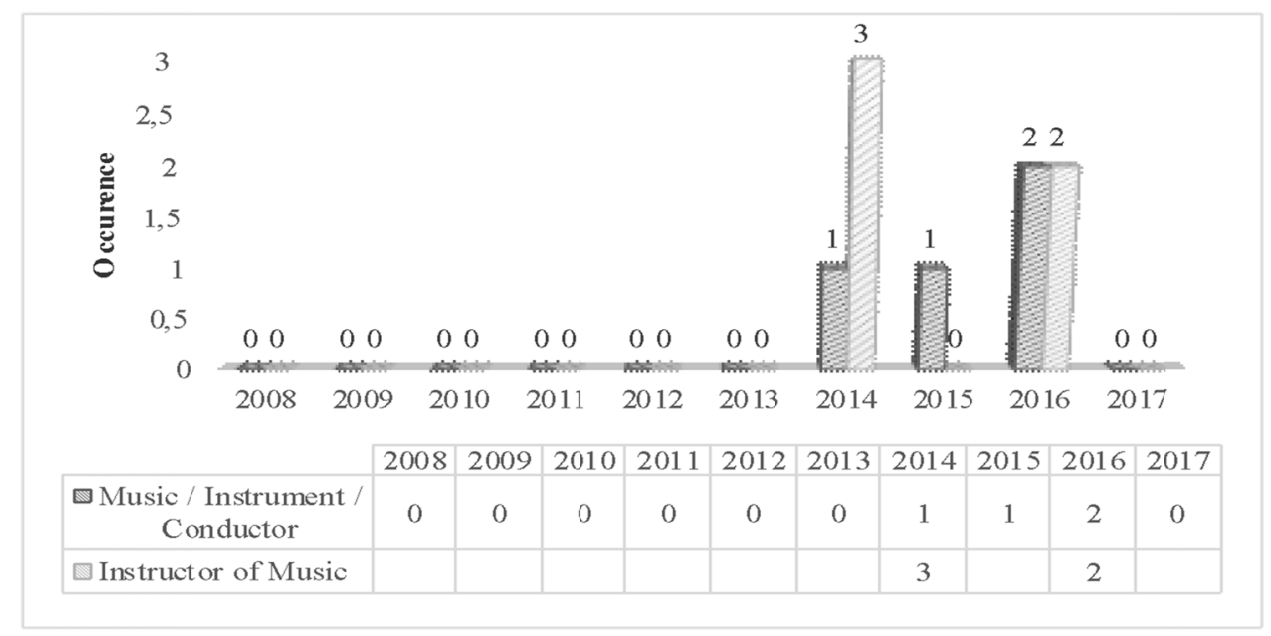

Figure 3. Music teacher/instructor

Source: the author

Another specification requested in the notices was the qualification in regency or musical instrument, with a degree in higher education recognized by the Department of Education and/or formation in high level with training certification in the instrument of operation for professionals in the area aimed at acting with the teaching of music in schools. It is highlighted, in this sense, that the professional in order to work in Basic Education must possess the degree of a licensee. It is possible, perhaps, in that sense, to point out some incongruity in the public tender.

\section{Conclusions}

The legislative meanders, when it comes to access to music in Brazil, were initiated with the arrival of the Royal Family in Brazil in 1808. Since then, procedures for music to be present in educational environments have confirmed the importance of its access to students in Brazilian schools.

In this sense, laws were sanctioned and modified, educational reforms came into effect, and influences through political actions that contributed to the cyclical trajectory of insertion and discontinuity of Music teaching in the Brazilian educational scenario came into effect to a greater or lesser degree.

Music, therefore, was effectively present in schools starting with the Orpheonic Singing, being evidenced by the educational actions promoted by Villa-Lobos. In 1964, the Orpheonic Singing was replaced by musical education, which, years later, was replaced by artistic education, with a focus in multipurpose teaching of arts in Brazilian schools.

After mobilizations involving associations, researchers, politicians, and the Brazilian society, Law No $11.769 / 2008$ was crucial for the reinsertion of music in schools. Besides this achievement which, despite its limitations, the mobilization for the inclusion of artistic languages (visual arts, dance, music, and theater), through Law No 13.278/2016, was another substantial gain for the teaching of art in schools.

With the Law No 11.769/2008, music became mandatory content in schools of Basic Education, but only with Resolution No 2/2016 came to integrate school curricula.

With this research, which proposed to identify public tenders in the municipalities of Rio Grande do Sul for hiring music teachers, it became evident the ambiguities in the interpretation of the political text, expressed in the context of the practice, about the effective hiring of music teachers in schools.

Considering the 2008 mid-2017 time frame, sixty notices were identified for the hiring of music teachers, whose formation specification consisted of a specific Degree in Music. Thus, out of the 497 municipalities in the state, 133 conducted these tenders.

From the Approach of the Policy Cycle, proposed by Bowe et al (1992) and Ball (1994), the text of the hiring notices for teachers to work with the teaching in art, artistic education, among other specifications evidenced in the data analysis, allow the interpretation and feasibility of the participation of music teachers in Basic Education, since the scope of professional performance is evidenced in the public notices due to the lack of specification of the artistic language of professional performance. In this sense, capable of this interpretation, understanding that 
music teachers could participate in the selective process for teaching in Basic Education, there were 133 added.

At the end of this investigation, it is understood that its expansion, seeking information on how it happens and how the pedagogical-musical actions are made possible in the schools of Basic Education in Rio Grande do Sul, for example, they can contribute to the understanding regarding social, pedagogical-musical and, mainly, policies for the implementation of access to music in Brazilian schools.

\section{Acknowledgements}

Bruno Felix da Costa Almeida, Christian Miquéias Braun, Eduardo Filipe Albrecht Lassig. Rio Grande do Sul Research Support Foundation (FAPERGS), National Council for Scientific and Technological Development (CNPq).

\section{References}

Ball, S. J. (1994). Educational reform: a critical and post-structural approach. Buckingham: Open University Press.

Bowe, R. et. al.. (1992). Reforming education and changing schools: case studies in policy sociology. London: Routledge.

BRASIL. (1854). Decree No. 1.331-A of February 17, 1854. Approves the Regulation for the Reform of Primary and Secondary Education of the Municipality of Côrte. Rio de Janeiro Palace on February 17th.

BRASIL. (1961). Law No. 4.024, of December 20, 1961. Establishes the Guidelines and Bases of National Education. Brasilia.

BRASIL. (1968). Law No. 5.540, of November 28, 1968. It establishes norms and organizations and functioning of higher education and its articulation with the middle school, and other measures. Brasilia.

BRASIL. (1971). Law 5.692, of August 11, 1971. Establishes Guidelines and Bases for the teaching of 1st and 2nd grades, and other measures. Brasilia.

BRASIL. (1973). Federal Council of Education. Decision No. 1.284, 1973. Secretariat of Education of the First and Second Degrees. Arts education: laws and opinions. Brasilia, 1973, including CFE Resolution No. $23 / 73$.

BRASIL. (1977). Federal Council of Education. Decision No. 540/77, of February 10, 1977, of the CFE. About the treatment to be given to the curricular components provided for in art. 7 of Law 5.692 / 71. Brasilia.

BRASIL. (1982). Law No. 7.044 of October 18, 1982. Amends provisions of Law No. 5.692, of August 11, 1971, concerning the professionalization of high school education. Brasilia.

BRASIL. (1995a). Law No. 9.131 of November 24, 1995. Amends provisions of Law No. 4.024 of December 20, 1961, and makes other provisions. Brasilia.

BRASIL. (1995b). Law No. 9.192, of December 21, 1995. Amends provisions of Law No. 5.540, of November 28, 1968. Brasilia.

BRASIL. (1996). Law No. 9.394, of December 20, 1996. Establishes the guidelines and bases of national education. Brasilia.

BRASIL. (2008). Official Gazette. Law No. 11.769 of August 18, 2008. Amends Law No. 9394/96, to provide for the compulsory teaching of music in basic education. Section 1. Brasilia: National Press.

BRASIL. (2013). Decision CNE/CEB No. 12/2013. National Guidelines for the operationalization of Music teaching $n$ Basic Education. Brasilia.

BRASIL. (2016a). Law No. 13.278, of May 2, 2016. Change $\S 6$ of art. 26 of Law No. 9.394 of December 20, 1996 , which establishes the guidelines and bases of national education, referring to the teaching of art. Brasilia.

BRASIL. (2016b). Resolution No. 2, May 10, 2016. Defines National Guidelines for operationalizing the teaching of Music in Basic Education. Brasilia.

Del Ben, L. M. (2005). A study with schools of the state primary school network of Porto Alegre - RS: subsidies for the elaboration of music education policies. Musica Hodie, 5(2), 65-89. Retrieved February 5, 2019, from http://www.musicahodie.mus.br/5_2/musica_hodie_5_2_artigo_5.pdf

Del-Ben, Luciana et. al.. (2016). About music teaching in basic education: an analysis of public tenders for teachers. Opus, 22(2), 543-567. 
Diniz, L. N. (2005). Music in early childhood education: a survey with teachers from the municipal school system of Porto Alegre - RS. Dissertation (Master in Music) - Postgraduate Program Master and Doctorate in Music, Institute of Arts, Federal University of Rio Grande do Sul, Porto Alegre.

Figueiredo, S. L. F. De., \& Meurer, R. P. (2016). Music education in the school curriculum: an analysis of the impacts of Law No. 11.769 / 08. Opus, 22(2).

Freitas, H., Janissek-Muniz, R., \& Mascarola, J. (2004). Use of the Internet in the process of research and data analysis. National Association of Research Companies (2004: São Paulo). [Annals]. [São Paulo: ANEP, 2004]. Retrieved February 5, 2019, from https://lume.ufrgs.br/handle/10183/4801

Hentschke, L., \& Oliveira, A. (2000). Music education in Brazil. In Hentschke, Liane (Ed.), Music education in neolatine language countries (pp. 47-64). Porto Alegre: Publisher of the Federal University of Rio Grande do Sul.

Koch, T. (1996, April). Internet search services. (Translation of a paper given at: "Further on the way to the virtual library! Libraries are using the Internet". Erste INETBIB-Tagung in der UB Dortmund, March 11, 1996.

Kraemer, R-D. (2000, Abr./Nov.). Dimensions and functions of pedagogical-musical knowledge. Em Pauta, Porto Alegre, 11(16/17), 50-73.

Lemos W. Júnior. (2012, Jan./Abr.). History of music education and the experience of orpheonic singing in Brazil. EccoS - Rev. Cient., São Paulo, (27), 67-80.

Moraes, R. (1999, March). Content analysis. Education, Porto Alegre: Pontifical Catholic University of Rio Grande do Sul, year XXII, (37), 7-31.

Penna, M. (2002, Set.). Music teachers in public elementary and high schools: a significant absence. ABEM Journal, Porto Alegre, 7, 7-19.

Penna, M. (2004a, Mar.). The double dimension of educational policy and music in school: - I analyzing legislation and normative terms. ABEM Journal, Porto Alegre, 10, $19-28$.

Penna, M. (2004b, Set.). The double dimension of educational policy and music in school: - II from legislation to school practice. ABEM Journal, Porto Alegre, 11, 7-16.

Queiroz, L. R. S., \& Penna, M. (2012, Jan./Abr.). Public policies for basic education and their implications for music teaching. Education, Santa Maria, 37(1), 91-106. Retrieved February 5, 2019, from https://periodicos.ufsm.br/reveducacao/article/viewFile/3662/2713

Requião, L. (2013, May-Aug.). Music in schools: commodity or human formation? Education: Theory and Practice / Rio Claro, 23(43), 169-181. Retrieved February 5, 2019, from http://educa.fcc.org.br/pdf/eduteo/v23n43/v23n43a11.pdf

Santos, R. M. S. (2005, Mar.). Music, reality in schools and training policies. ABEM Journal, Porto Alegre, 12, 49-56.

Souza, J. V. et al.. (2002). The music at school. In What does music at school do? Conceptions and experiences of elementary school teachers. Studies Series (November). Porto Alegre.

\section{Copyrights}

Copyright for this article is retained by the author(s), with first publication rights granted to the journal.

This is an open-access article distributed under the terms and conditions of the Creative Commons Attribution license (http://creativecommons.org/licenses/by/4.0/). 